\title{
Effectiveness of the Use of Personal Protective Equipment (Ppe) by Cadet on Board
}

\author{
Iksiroh El Husna, Wisnu Handoko, Sarifudin, and Anissofiah Azise Wijinurhayati
}

\begin{abstract}
Work accidents according to Heinrich $\mathbf{8 8 \%}$ are caused by human factors so that they can be prevented, so improving the behavior of workers becomes very important. The study was conducted on cadets post-sea practice, against the use of personal protective equipment (PPE). The research method was carried out quantitatively by distributing questionnaires to 150 people (75 cadets of nautica and 75 cadets of technics / machines). The results showed that the understanding of cadets on the function and usefulness of PPE when on board was relatively high $(90 \%$ - $90.8 \%)$. However, the use of PPE on board is relatively low $(83 \%-84.8 \%)$. So it can be concluded that the understanding of cadets against PPE is high enough but still reluctant to use it completely and correctly. The reason they did not use, because PPE is not suitable to use due to poor maintenance. For that to the management of the ship to carry out routine maintenance, so that PPE can be used to the maximum extent possible.
\end{abstract}

Index Terms - Personal protective equipment, safety, productivity.

\section{INTRODUCTION}

$\mathrm{W}$ hen there is a work accident, one thing that immediately comes to mind is what caused the accident. Basically there are two things that can cause safety problems (and also health). First, conditions are not safe or unsafe conditions. Second, human behavior is risky or unsafe / at risk behavior. The application of work safety procedures in the workplace as well as on board is very necessary to achieve zero accidents, namely ship accidents to zero. The high rate of accidents in the workplace due to human factors (Heinrich, 1912) places unsafe acts (unsafe behavior) as the biggest contributor to accidents by $88 \%$. Whereas according to Dupont (in Heinrich) up to $96 \%$. One

Iksiroh El Husna is with the Nautica, Semarang Merchant Marine Politechnic, Semarang, Indonesia.

Wisnu Handoko is with the Nautica, Semarang Merchant Marine Politechnic, Semarang, Indonesia.

Sarifudin is with the Technic, Semarang Merchant Marine Politechnic, Semarang, Indonesia.

Anissofiah Azise Wijinurhayati is with the Nautica, Semarang Merchant Marine Politechnic, Semarang, Indonesia (e-mail: Anissofiah@gmail.com). behavior that does not survive while working is not using personal protective equipment (PPE). Every company or workplace such as a ship is obliged to provide personal protective equipment and always provide socialization to its workers about the use of personal protective equipment in order to reduce accident rates.

Law No. 1 of 1970 concerning Occupational Safety mandates companies and workers (seafarers) to implement the use of PPE, to guarantee and protect the safety of every workforce and other people in the workplace. So that, every company or workplace such as a ship is obliged to provide PPE and always provide socialization and supervision to the workers about the use of PPE (Tadesse, 2016; McLaughlin 1999). The company has an obligation to provide training on the use of PPE. An important element of training according to OSHA is ensuring that workers understand to use PPE correctly, examine, maintenance, and maintain it for maximum sustainable protection (Nussbaum, 2000)

This includes the company's obligation to clean work clothes (Kelsch, 2010). The obligation to use PPE is reinforced by the Minister of Manpower and Transmigration Regulation No. Peter. 08/Men/VII/2010 regarding personal protection. According to OSHA in the United States every year, there are thousands of workers who face and eye injuries because they do not use PPE (Elliot, 2003). For this reason, collaboration between workers and employers is very important in the determination and selection of PPE tailored to the needs of workers. (Hoff, 2013). The basic principles of OSHA for PPE self-assessment of potential hazards faced by workers (Anonim, 1994) An ILO code of practice. Second edition (revised). Geneva, 1996. xiv +194 pp. Appendices, index. 27.50 Swiss francs. ISBN 92-210945 which discusses the prevention of work accidents on board and ports related to the use of PPE.

If a work accident occurs, it will certainly reduce the company's performance due to the decreasing productivity of workers. Small investment with large returns, that's the message of the HSE (Health, Safety and Environment) professionals on the company's management of the existence of PPE (Anonim, 2002)

The obligation to use personal protective equipment has become a joint agreement with the government through the Ministry of Manpower and Transmigration. As stated in the Minister of Manpower and 
Transmigration Regulation No. Peter. 08 / Men / VII / 2010 concerning personal protection. So that each company is required to provide PPE to employees to expedite the work system and work safety and health within the company.

Many of these fatal work accidents (fatal accidents) are caused by employees who do not use or neglect to use PPE. Like an accident that occurred on November 4, 2017 on board the KM Kebon Karet owned by PT Samudera Inti Perkasa in the waters of Banjarmasin, South Kalimantan. One of the ship's crew did not use safety shoes while working, his fingers were hit by a winch need to amputation because it had been destroyed (Syafii, 2017). Work accident aboard the MV cargo ship. Mandona is Balinese-flagged from Xianngang to Singapore. On the way to contact SAR Banda Aceh because there was one of the crew who had a work accident that caused the hands to tear due to not using gloves while working (Masriadi, 2017) When compared with other countries, work accident events in Indonesia occur more often due to lack of understanding of how to use PPE. Therefore, counseling or training on the use of PPE is needed for all employees Cadet is taruna / taruni from merchant marine polytechnic who is carrying out the sea project as a requirement to comply get a marine diploma. As well as cadets from PIP Semarang also have the task to complete the sea project period for 12 months. Cadets will be trained to become a commercial shipping officer, namely learning and training to operate the ship. In MLC 2006 (Maritime Labor Convention, 2006) states, On the assumption that cadets are performing work on the ship, although under training, they will be considered as "seafarers". So cadets must also comply the requirements to use PPE correctly.

In addition, it is necessary to implement SMK3 (Occupational Health and Safety Management System). The implementation is needed for workers to understand well the importance of occupational safety and health including the importance of using PPE for their safety and around the scope of their work. So as to create a work atmosphere that is comfortable and safe, there are no smallest work accidents or fatal accidents caused by non-compliance and neglect of workers against the use of PPE. After the implementation of SMK3, companies also need to monitor and pay attention to workers who work using PPE. Is PPE used in accordance with the requirements and needs of the workforce, no one is lazy and negligent in using PPE. Monitoring of the use of PPE and PPE care must be routinely carried out, so that in its use it is more optimal and the work environment is safer and more comfortable.

\section{Personal Protective Equipment}

PPE that must be used includes tools that can protect all parts of the body from head to toe which includes a helmet, glasses, mask, ear plug, ear muff, gloves, wear pack, shoes. In certain jobs requiring specific personal protective equipment such as chemical tankers that have very dangerous loads will be different from ordinary charged vessels such as cargo ships or container ships.

Personal protective equipment can be divided into 3 groups, namely:

1. Head Protective Equipment including: Helmet, Safety Glass, Mask, Respirator, Ear Plugs and Ear Muffs.

a. Safety helmet

Helmet or Protective Cap is used to make head protection from exposure to hazards such as falling objects or exposure to electrical hazards. The use of a Protective Helmet must match the head circumference until it is comfortable and efficient to protect it.

There are 3 types of helmet based on their protection on electricity, namely:

1). General Type Helmet (G) that can protect the head from bumping and falling objects and reduce exposure to danger of low-voltage electricity to 2 . 200 Volts

2). Electrical Type Helmet (E) that can protect the head from bumping and falling objects and reduce exposure to danger of high voltage electricity up to 22,000 Volt

3). Conductive Type Helmet (C) which can only protect the head from bumping and falling objects but does not protect the head from exposure to electrical current hazards.

b. Protective Glasses (Safety Glass)

Protective Goggles are tools used to make eye protection from the danger of jumping sharp objects, dust, small particles, reduce the dazzling light and splashes of chemicals. Protective Glasses are divided into 2 types, namely:

1). Safety Spectacles, in the form of general glasses and can only protect the eyes from the danger of jumping sharp objects, dust, small particles and reduce the dazzling light.

2). Safety Goggles, Glasses that have a shape attached to the face, eyes can be protected from the danger of splashing chemicals, smoke, steam, dust and sharp objects.

c. Ear Plugs

Earplugs or Ear Plugs are used to make hearing aids protect the ears from high intensity intensity. Using Ear Plug, Tone Intensity can be reduced to $10 \sim 15$ dB. Ear Plugs are generally used by workers who work in areas that have high machine tones.

d. Ear Muffs

Ear Muffs or Ear Muffs are the tools used to protect hearing devices from high Tone Intensity. Ear Muffs can reduce tone intensity to $20 \sim 30 \mathrm{~dB}$. Ear Muffs are divided into Head Bands and Ear Cups made of foam pads to protect the outer ear (earlobe). Ear Muffs are often used by Engineers and Generator Technicians.

e. Mask

That is the tool used to protect respiratory equipment such as the nose and mouth from possible hazards 
such as soldering smoke, dust and mild chemical odors. Masks are generally made of cloth or paper.

f. Respirator

The respirator is a device used to protect respiratory equipment such as the nose and mouth from possible hazards such as soldering smoke, the smell of chemicals, dust, steam, gas and mist particles and Fume particles. Respirators are often used by Soldering Machine Technicians, Painting Operators and other chemical systems.

2. Body Protective Equipment include: Apron

Apron (Apron): That is body protection equipment from chemical splashes and hot temperatures.

3. Protective limbs one of them, namely: Protective Shoes (Safety Shoes / Boot), Gloves (Hand Gloves).

a. Equipment used to make hand protection from chemical contact, scratches or hand wounds due to touch with sharp and sharp objects. Gloves are generally used in chemical preparation systems, installation of rather sharp components, heating systems and so on. Some types of gloves include one of the following:

1). Cotton Gloves, used to make hand protection from scratches, cuts and light cuts.

2). Leather Gloves (Leather Gloves), are used to make hand protection from scratches, cuts and light cuts.

3). Rubber Gloves (Rubber Gloves), are used to make hand protection from contact with chemicals such as Oil, Oil, Adhesives and Grease.

4). Electrical Gloves, are used to make hand protection from contact with electric currents that are low to high voltage.

b. Protective Shoes (Safety Shoes / Boot)

equipment used to protect the foot from falling objects, sharp objects such as glass or pieces of steel, chemical solutions and electricity. Protective shoes are fitted with steel at the end with rubber band.

\section{ReSEARCh Methodology}

This study uses a quantitative method with questionnaire distribution with the use of likert theory and is equipped with in-depth interviews with cadets post prala (marine practice) as a population by taking a sample of 75 cadets in the nautics department and 75 cadets majoring in engineering/ machinery.

\section{Results And Discussion}

The study was conducted on 150 cadets $(75$ cadets of Nautica Study Program and 75 cadets of Engineering / Machinery Study Program). From the results of the research that cadets' understanding of Personal Protective Equipment (APD) was obtained by cadets during education and training in BST (Basic Safety Training) on campus, $86.5 \%$. The understanding of cadets was obtained because at the time of the Education and Training program demonstrations were conducted
$(84.6 \%)$ and cadets demonstrated it $(82.2 \%)$. So that cadets as much as $(80 \%)$ can explain the functions and uses of each PPE. At the time of BST Training before practical learning, cadets used complete PPE (73.0\%). Of the 150 cadets $77.0 \%$ were correct in using PPE. Cadets who know various types of PPE (from head to foot) $90.3 \%$ and know and understand the function of PPE as much as $90.8 \%$, as well as knowing the risk of not using APD 90\%. BST instructors / instructors participate in monitoring cadets in the use of PPE and always check routinely on PPE on campus.

Based on the knowledge gained on campus, then when on board the cadets can immediately adjust to the PPE on board. As many as $86.9 \%$ of cadets understand the PPE that is on the boat. Both the PPE used when working in Deck (84.8\%) and in the engine room $(83.0 \%)$. Ship management provides PPE for $80 \%$ of daily activities and also the reserve APD in the store as much as $82.6 \%$. Ship officers (First Deck Officer) as the person in charge of ship safety perform PPE maintenance (76.8\%).

In this research aims to determine how well the knowledge and understanding of cadets about PPE for the safety of life on board and to know the risks that occur when not using it. From the data above that the understanding of cadets against PPE when on campus or while on board is relatively high but there are still cadets who do not use PPE while working due to PPE that is not well maintained and not suitable for use so that cadets have the assumption that using or not wearing the same risk and uncomfortable.

\section{CONCLUSION}

From the research data above it can be concluded that the cadets have gained knowledge and understanding of PPE when on campus. But the percentage of correct and complete usage decreases compared to the knowledge and understanding. This can be caused by several factors including ignorant cadets for self-safety and not serious in carrying out education and training activities on campus, even though they know the risk of improper and complete use of PPE and the teacher also always monitors.

The cadets' knowledge of PPE on board is higher than their understanding when on campus. But it is not offset by the use of PPE on board. One factor that causes it is that cadets follow the behavior of officers or crew on board. The management has completed the availability of PPE, but PPE treatment is still low. So that many tools are damaged and not suitable for use so this also causes the reluctance of cadets and officers / crew to use PPE.

\section{Suggestions And Recommendations}

Suggestions and recommendations for the ship management company to carry out maintenance and supply of adequate and appropriate equipment. So that 
cadets on board and officers / crew members are not reluctant to use PPE while working.

\section{REFERENCES}

[1] Anonymous, "Safety Gets Personal". Small Business Reports Vol. 19, Iss. 11,pp 22. New York. Nov., 1994.

[2] Anonymous, "Personal Protective Equipment and OSHA," The CPA Journal, Vol 64 (10). (Okt 1994): 9. New York, 1994.

[3] Anonymous, "Management must understand costbenefit of PPE, ISEA says," Professional Safety :Des Plaines, Vol 47(8). pp.1.Aug 2002

[4] A. Barbara, MPH, "Personal Protective Equipment: Design and Availability Considerations," Occupational Health Nursing : Atlanta, Vol. 30, Iss. 10, pp.33-37. Oct., 1982.

[5] B. Bernard R. "Eye and Face Personal Protective Equipment," Waco, Vol. 66, Iss. 3, pp.30-42. March, 1997.

[6] Elliot, Fred. "Effective Use of PPE," Occupational Health \&Safety : Waco, Vol. 72, Iss. 11, pp.76-78. Nov 2003.

[7] H.W Heinrich, Industrial Accident Prevention, Vermont Amerika. 1931.

[8] International Labour Organization, Maritime Labour Convention 2006, Fourth edition, 2015.

[9] S. Joseph, "The Role of Personal Protective Equipment in Workplace Safety," Electrical Apparatus, Vol 66 (9). Pp.32-34. Chicago. Sept., 2013.

[10] S. Joseph, "Saving Face," Electrical Apparatus, Chicago, Sept., 2014.

[11] N. Julie, "Effective Training: Covering the Base," Occupational Health \& Safety ; Waco, Vol. 69(12), pp.52-56+. Dec., 2000.
[12] N. Kelsch, RDHAP, Personal Protective Clothing, RDH ; Tulsa. pp.82-84, July 2010.

[13] J. McLaughlin, Who Pays for Personal Protective Equipment?, OH \& S Canada : Don Mills Vol. 15, pp.22-23. Jul/Aug 1999.

[14] Republik Indonesia, Peraturan Menteri Tenaga Kerja dan Transmigrasi, Nomor PER.08/MEN/VII/2010 tentang Alat Pelindung Diri, Jakarta, 2014.

[15] P.D Saut, , "Angka kecelakaan kerja RI meningkat ke 123 ribu kasus di 2017," Detik Finance, 2017.

[16] A. Sebestyen, Managing a PPE Program, OH\& S Canada: Nov/Dec 1993:9,6; ABI/INFORM Global pp.26, 1993.

[17] S. Tadesse, S, "Utilization of personal protective equipment and associated factors among textile factory workers at Hawassa Town, Southern Ethiopia," Journal of Occupational Medicine and Toxicology, Vol 11(6), Ethiopia, 2016

[18] Republik Indonesia, Undang-undang No.1 Tahun 1970 tentang Keselamatan Kerja. Jakarta, 1970.

[19] Anonymous, http://www.ergonomi-fitblogspot.com/2013/10/keselamatan-berbasisperilaku-behavior.html. Accessed 24 April 2018.

[20] Anonymous, http://www.liputanbmi.com/baca/2387/dua-jarikakinya-diamputasi-akibat-kecelakaan-kerja-pelautini-mengaku-belum-mendapat-haknya. Accessed 10 February 2018.

[21] Anonymous, https://regional.kompas.com/read/2017/08/23/06055 181/kecelakaan-kerja-di-laut-abk-asal-suriahdievakusi-. Accessed 10 February 2018. 